\title{
Methods and principles of unified personal protective equipment during chemical industrial catastrophes
}

\author{
LACZIK Balázs ${ }^{1}$
}

\begin{abstract}
The chemical industry plays a key role amongst the industries in the economic powers that make the world turn. The future of developing countries - taking cur- rent issues into account - is based on their chemical industry, and so it has been undergoing a development at a substantial pace.

However, in these countries security is not interpreted similarly to developed coun-tries, and cases have shown that there might be problems (Venezuela, Amuay refin-ery fire, caused by a lack of maintenance). In a domestic context, a good example is the red sludge disaster that happened on October 4 in 2010. The civilian population of the affected area had to be evacuated and a number of civilian organization, non-professional and professional rescue organizations participated in the damage control. During the implementation of damage control, civilian organizations had to be equipped personally and protectively. The aim of this article is to show the cri-teria that determine the level of necessary personal protection in terms of efficiency.
\end{abstract}

\section{Preface}

Investigating the disasters, I have come to the conclusion that the care of personal protection after a disaster can be possibly overdone in many cases. Below, I examine the factors that may be taken into consideration during a chemical disaster to provide the proper protection of the participants according to what tasks they perform and in which capacity they are at the affected area. Taking the different modes of personal protection care into account, the protective equipment complying with both the population and non-professional rescue orga- nizations and professional rescue organizations can be determined.

\section{The chemical disasters, characteristics of accidents and their place among the types of disasters}

In 2011, Hungary's unified disaster management system underwent a major transformation. During the conversion, many basic laws were altered or recreated. A new Civil Protection Act was introduced, which already included the basic principles of civil protection. According to the Hungarian Act art. para. 3 (5) of Act CXXVIII. of 2011, the definition of disaster is: "An emergency is announced in a situation when people's life, health, financial assets, basic care of population, natural environment and natural assets are threatened in a way that the dam- age, prevention and the consequences exceed the possibilities of protection. So introduction of special action is needed. Furthermore, continuous and strictly coordinated cooperation is

1 email:balazs.laczik@gmail.com 
needed from the local government and the state authority. In addition, international assistance has to be included." [1]

The above mentioned act determines what the definition of disaster is. However it does not classify the disasters into categories. Hence, it can be found only in literature. The classification of disasters can be defined according to the following features:

1. character (origin);

2. extension;

3. speed of procession;

4. intensity;

5. according to space and time.

In this case, classification according to the character (origin) is the most expedient. On the basis of the character (origin) three additional subcategories can be differentiated:
A) Natural disasters
1. geological;
2. hydrological;
3. meteorological;
4. biological.
B) Artificial type of disasters
1. armed conflicts;
2. economic conflicts (crisis);
3. terrorist acts.
C) Civilizational disasters:
1. chemical;
2. nuclear;
3. biological;
4. social.

The artificial kind of disasters and civilizational disasters belong together due to the fact that they are caused by human acts in most cases. So they can be combined in a group. As for the causes, in terms of chemical disasters, they may be the results of either a direct or an indirect effect of a disaster. For example: an earthquake, willful or negligent human acts or errors. This last one can occur during design, construction or operation. Industrial disas- ters may occur due to technological failures, however it is becoming less common because of the high level of industrial development and the demand for high security. Although in developing countries, industrial accidents can occur owing to technological failures, which may escalate a catastrophe. In addition, the misapplication or misoperation of technology, when the technological equipment is not properly maintained, can lead to industrial disasters (for example, Amuay refinery fire in Venezuela, 2012.).

In order to explore the characteristics of industrial disasters we need to have an over- all picture of the different kind of factories and groups. Generally, there are characteristics that are common in all types of industrial disasters but the nature of the accidents differs. The chemical industry can be grouped on the basis of two criteria:

- characteristics of the materials used, based on their nature;

- according to the type of industry.

The materials used can be classified according to the perilous features of the substance. These could be flammability (explosive), or toxicity (dangerous for the environment). Perilous 
features themselves do not necessarily need specific instructions during the procedure. It is im- portant to know the state of the substance, is it a gas, liquid (whether it goes with steam forma- tion or not) or solid. The nature and quality of the prevention depends on the state of substance.

As is usual, the chemical industry is divided into the following major groups:

- petroleum establishments (facilities);

- food establishments;

- general chemicals (such as detergents);

- pharmaceutical industries;

- agricultural chemicals (fertilizers, products of biocides and pesticides);

- military chemical (toxic gases, explosive materials).

After the classification of chemical facilities, the characteristics of each facility can be determined as either unique to a particular type of plant or organization, or more likely to occur. The specific feature of each chemical accident is the rapid formation and spreading. [2] While a flood can be predictable, well defined antecedents help in the detection.

Howev-

er, chemical accidents — in contrast with the above mentioned disasters - occur suddenly. Owing to the rapid formation, the event as a whole, cannot be considered as a particularly serious disaster (compared with an earthquake). However, due to rapid development, the set- ting of adequate forces and equipment for effective damage control and eradication is more difficult to implement. Thus the spread of damage is much easier. In addition, of course, there are events that take on a rapid and large size in a short period of time (e.g. the red sludge disaster). Material-specific equipment is required in the damage control of plant disasters. The equipment used by the intervening forces should be separately organized in order to determine how to approach the area of damage and what kind of procedural rules to use. The extent of the damaged zones alters quickly with a gas or vapour cloud. Thus appropriate pub- lic security should be provided (the execution of evacuation and sheltering, etc.). Changes of meteorology, and the environmental (terrain) conditions have a deep influence on the dam- aged zones. Therefore the exploration of industrial disasters are special. It is done accord- ing to a uniquely structured procedure (meteorological observation, material identification etc.). Original causes should be taken into account during the damage control of industrial disasters. Certainly, the precise circumstances cannot be defined in many cases, however the management of the factory can give an explanation roughly for the original conditions. The reasons of formation can be divided into two major groups: internal and external factors. An external event may lead to an external factor that affects the normal condition of the institu- tion. Moreover, it could result in the malfunction of the establishment.

These events could be:

- domino effect, other disasters (natural disasters), the effects of accidents;

- failure of related infrastructure;

- deliberate human acts (e.g. terrorist acts).

The group of internal factors is related to certain designers or the institution itself. Errors arising during design, construction and operation have been proved to be causes of a disaster. Internal factors can be classified in the following way:

- design errors (insufficient capacity of certain structures);

- construction errors (deviation from plans, installation of low quality materials);

- violation of operational rules;

- other reasons (e.g. experimentation). [3] 


\section{Staying on the industrial damaged zone, grouping and tasks}

Industrial damaged zones cover the industrial area and in many cases the harmful effects extend over the fence and threaten dwellers' lives. For effective damage control, the rescue organizations should cooperate with the factory workers and the factory management. Be- yond the mitigation and prevention of the spreading damages, inhabitants should be settled in designated safety zones.

The organization and implementation order of the emergency largely depends on the situation after damage, the environment, the state of surrounding establishments, the damage caused to public works and what type of risk should be eliminated. For instance, during a petroleum storage tank fire it is enough to order sheltering, but in case of an escape of a toxic vapor, sheltering may not be sufficient as a protective measure for the population. [4]

Based on the participation in the rescue work, attendants could be divided into three groups:

- civilians;

- factory workers, non-professional rescue agencies, organizations;

- professional rescue organizations.

Next, I will take stock of the recovery and rescue work that characterize factory damage. Then I will look into the implementation that should be done in the damaged zone. During factory disasters the following tasks need to be performed:

- alerting factory workers and the affected population;

- technical exploration, searching for victims and determination of possible perilous sources;

- saving lives, saving the wounded under the ruins;

- localization and extinction of the fire;

- localization and instant restoration of utility and power cables;

- opening gateways to the disaster zones and preparing work areas for the application of machinery;

- taking vulnerable establishments and buildings into account;

- elimination of unstable structures and perilous sources of danger;

- first aid and relocation of the population.

Hereafter, I am going to detail the obligations and tasks of those affected by the industrial catastrophes. The above mentioned enumeration implies a general task. The determination of the detailed tasks largely depends on the situation and the guiding of the damage prevention. However the execution of rescue works happen in the above mentioned logical order in all cases.

\section{Civilian population}

The task of the civilian population can easily be described. They have to collaborate with the rescue organizations and execute the tasks set by them. On an area contaminated with poisonous substance it is necessary to provide individual protective equipment for the popu- lation and supply them with relocation if it is needed. In order to perform a rescue it is nec- essary to organize the suitable modes of transportation and the itinerary has to be assigned 
as well. But it is not enough merely to rescue the population. Before entering the reception area, people have to be decontaminated. The organization of this procedure belongs to the experts who are responsible for damage prevention. More alternatives can be possible but the detailed description of those are not part of this current study. The population has to execute the instructions in connection with the decontamination. Furthermore, in case of need they have to use the protective equipment properly in order to maintain their security. Moreover, when required, people have to take part in a medical examination. After transportation away from the contaminated area, the population has to be decontaminated then they can occupy the assigned reception area. As long as they are not allowed to go back, they have to live in accordance with the rules valid for the reception area.

\section{Plant workers}

As for the plant, the leaders and the workers should create - as much as possible — the suitable conditions for the execution of damage prevention for both the professional and non-professional organizations. By this, I mean the organizational events, which make dam- age prevention more effective. Leaders of the plant - on the basis of their location and technological knowledge - are obliged to supply unconditionally all information related to damage prevention for those who participate in the execution of damage prevention. Fur- thermore, the opportunities of the technology should be made use of during the rescue work. Moreover, injured parts should be sectionalised and removal of perilous chemical agents from the endangered area should be started (e.g. emptying of surrounding containers and drawing off the dangerous substance from the injured technology). In case of the harm of the operating equipment and devices used in averting damage prevention the firm's management has to maintain immediate restoration or salvage of the damaged elements. Providing that the firm has the possibility, it should prepare the road to the location of the catastrophe and open passages.

\section{Non-professional rescue organizations, civil organizations}

Those non-professional organizations, who do not have the suitable equipment for working on the damaged zone may be perfectly appropriate on the border of it - where considerable human resources are in need - so as to operate a supporting and developing boundary.

These rescue organizations might be volunteers, civilians or currently formed non-pro- fessional rescue organizations in our country (used to be called civil defence organizations). It is not necessary for the individual protective agencies to accomplish such a high protective level in order to operate the relief corridors and gates on the border.

These forms can be found at non-professional rescue organizations (in many cases orga- nizations have suitable equipment for intervention tasks as well). In addition, they have the right qualification to apply these devices. As a result, non-professional rescue organisation's major task is to accomplish support and help interventions. Obviously, there are non-pro- fessional rescue organizations who can take action in the contaminated area in case of an industrial catastrophe. So their tasks are the same as the professional rescue organizations'. Furthermore, rescuing the population from the endangered area or from the assigned evacu- ation zone is a top priority. 
For rescue from the endangered zones it is necessary to organize the appropriate transport vehicles and the necessary supply for their operation (primarily fuel). The above mentioned vehicles and the population need to be decontaminated as soon as they are evicted from the perilous zone. Rescue works need to be insured on the particular route and according to the particular order.

\section{Professional rescue organizations}

Professional rescue organizations fulfill the tasks of damage prevention in the contaminated area. After exploration they start rescuing the injured and those trapped under the ruins. In line with rescuing the injured they start extinguishing fire. They have to take great care in case of an explosive and flammable environment. Sources of flame and explosion need to be eliminated as soon as possible. Public utilities, energy cables and the immediate restoration works are not beyond a professional rescue organization's range if the workers of the industry are not able to accomplish these tasks (ie they are not able to approach the location or they do not have the right safety equipment). In this case, it is practical to ask for collaboration from someone who is absolutely aware of the damage and knows how to restore it. So then professional rescue organizations with suitable vocational support can take steps in order to start immediate restoration.

To guarantee safe working conditions sources of danger must be eliminated. In many cases, weak constructions need to be pulled down. Furthermore, leakage and any sources of danger can only be ceased by the aid of the rescue organization's equipment. It is necessary to collaborate with the firm's management and the firm's workers so as to explore the sources of danger. They can recognize sources - because of the specific and technological versatility of the firm - which might be ignored by the professional rescue workers.

In conclusion, it can be clearly seen what tasks have to be done on the endangered area. As a result, requirements for the safety equipment can easily be formulated. In the following, I introduce requirements for personal protective equipment.

\section{Requirements of personal protective equipment}

Currently, a wide range of personal protective equipment is known. These items are different not only in type but the level of protection they provide. During the development of personal protective equipment the better and higher level of protection they can provide, the wider the spectrum they are suitable for, especially in case of the appearance of a lot of chemical substances. The aim of personal protection is to create the appropriate working conditions of the intervening organizations in the contaminated area and to develop the population's ability to rescue themselves. In terms of industrial catastrophes the types of personal protection can be differentiated as following:

- respiratory protection;

- skin protection;

- mechanical protection;

- radiation protection;

- protection against fire (flame effect) and thermal radiation. [5] 
In case of industrial catastrophes, the major aim of protection includes respiratory and skin protection. Additionally, the prominent principle is protection from the effects of per-ilous chemical substances. As for the personal protective devices we distinguish filtering devices from insulating protective equipment. Besides, steps should be taken in order to protect oneself against other dangerous effects (e.g. mechanical protection, fire and heat pro- tection, radiation, electric shock etc.). Protection against jeopardizing effects is decided by the current situation. The method of protection for the intervening organization is defined by the leader of the rescue organization. The plant's workers - if the plant is identified as a dan- gerous one - have the appropriate personal protective devices in case of any harmful effects caused in the plant. These devices need to be included in the safety documentation by the manager (safety report, analysis, serious damage aversion plan). The manager has to provide his employees with the right training. The levels of personal protection and the requirements of the personal protective equipment are defined in the domestic legal regulation in Art. para.

4 of Act 2/2002. (II. 7.) SzCsM. (Minister of social and family affairs) order:

\section{$1^{\text {st }}$ category}

"The first category includes such kind of protective equipment of which the manufacturer supposes that the user is able to safely determine how protective the device is. Moreover, the user has to be aware of the proper time when to use it and how to use it. The level of protec-tiveness can be certified with an EK declaration of conformity. The user guide is essential.

According to this, protective devices belong to the first category needed to provide protection against the following effects:

- mechanical dangers causing surface injury (e.g. gardener gloves, finger protector);

- cleaning supplies causing mild aggressive effects (e.g. diluent detergents);

- treatment of objects with less than $50{ }^{\circ} \mathrm{C}$ surface temperature;

- treatment of objects without dangerous kick (e.g. gloves, apron);

- not exceptional or extreme meteorological circumstances (head protection, clothing against weather);

- mild hits and vibrations, not causing enduring injuries (protection of scalp and hair, gloves);

- solar radiation (sunglasses).

$2^{\text {nd }}$ category

Protective devices which do not belong to the first and third category belong to this category.

\section{$\mathbf{3}^{\text {rd }}$ category}

Here are complex designed protective devices. They protect against the effects of lethal accidents and serious irreversible health impairment. The manufacturer supposes that the user cannot recognize the direct effects in time.

- the filter type respiratory protective devices protect from solid substances, liquid aerosols or irritating, dangerous, toxic and radiotoxic gases;

- respiratory protection devices totally isolated from the atmosphere, including aqualungs;

- provides limited protection against chemical effects and ionizing radiations;

- in an environment exposed to heat where the value of the environmental air reaches/ exceeds $100^{\circ} \mathrm{C}$,

- protective devices against cold environmental effects, if the environmental temperature is under $-50{ }^{\circ} \mathrm{C}$, 
- protection from falling down;

- they protect from the risky factors caused by electricity, in work done near voltage and help in isolating from equipment under high voltage. [6]

On the basis of the law each protective device can be classified in the third category. However, the practical side needs to be approached as for the level of personal protection in the study.

The practical approach is as following [5]:

\section{Protection, type A}

Circumstances defining dangerousness:

- unknown chemical substance or known chemical substance in a big concentration and the airspace has an oxygen deficiency $(<20 \% \mathrm{~V} / \mathrm{V})$;

- direct contact with the dangerous substance can cause serious health impairment. It can be absorbed through skin and causes poisoning. (e.g. toxic agents);

- work in the contaminated area can last longer.

Applicable protective devices:

- insulator type protective clothing;

- insulator type respiratory protective device (worn under the protective clothing).

\section{Protection, type B}

Circumstances defining dangerousness:

- the concentration of the air pollution is not known, or the concentration does not make filter type respiratory protection usage possible and the airspace has an oxygen defi- ciency ( $<20 \% \mathrm{~V} / \mathrm{V})$;

- being in contact with the dangerous substance, skin can be irritated or injured, but not

seriously. (e.g. corrosive agents).

Applicable protective devices:

- insulator type protective clothing;

- insulator type respiratory protective device.

\section{Protection, type $\mathbf{C}$}

Circumstances defining dangerousness:

- the air pollution is low and it makes possible the use of filter type respiratory protective devices;

- the suitable type of filter cartridge is available;

- the oxygen content of the airspace is at least $20 \% \mathrm{~V} / \mathrm{V}$;

- being in contact with the dangerous substance, skin can be irritated (e.g. irritating, stimulant substance).

Applicable protective devices:

- insulator type protective clothing;

- filter type protective clothing.

\section{Protection, type D}

Circumstances defining dangerousness:

- the concentration of air pollution is very low;

- contact with dangerous substance, skin will not be irritated.

Applicable protective devices:

- filter type protective clothing and rubber boots:

- filter type respiratory protective device; 
- the above mentioned categories and levels of protection give directions for the ap- propriate mode of protection. Those who make decisions have to be aware of how dangerous the substance is and what chemical and physical features characterizes the substance. Decision makers also have to know the effects of the substance.

\section{Requirements of the personal protective equipment [5]}

Taking the conservative approach into account, after the event of damage (approaching from the safety side) the civilian population needs to be evacuated. Seclusion is not enough inside the borders of the safety zone, therefore rescuing has to be organized. To leave the contaminat- ed area and to escape securely, it is necessary to apply regular or temporary personal protective devices which provide conditions for the one seeking refuge and protect him from harmful ef- fects. The supply of the personal protective device for the population can happen in three ways:

- they have been distributed (people store them at home);

- they are stored in a central place near the firm;

- they are stored in a regional store-house and the equipment is fitting for regional dan- ger sources.

Distributed personal protective devices basically have to be simple and easily applied It is not possible to teach the whole population to use personal protective devices. The usage of a gas mask does not appear to be complicated, although in order to use it in the correct way short training is needed. Despite the fact that there is a short description on how to put the device on, and how to set the size and how to use it properly, experience shows that in real life situations problems always arise. Certain protective devices have to be universal because of the different head sizes. According to the requirements they have to be suitable for both adults and children and should be worn in a way that neither the possible stubble (harsh stub- ble worsens the suctions of gas masks) nor glasses can influence the application. Generally, rescue happens on transport vehicles. One vehicle makes the transport until the border of the contaminated area, the usage of personal protective equipment is obligatory on the vehicle. After decontamination, another vehicle transports people to the receptive area. So on the basis of the above mentioned facts, the protective devices' validity of protectiveness needs to be examined. Generally, rescue from the contaminated area and the decontamination together should not exceed the validity of the protective device.

All in all, requirements of the distributable protective equipment for the residents are the following:

- easy application;

- protective ability set to vulnerability;

- universal size;

- the possible longest protection time.

Primarily respiratory protective devices are needed to rescue the population. In addition, the protective equipment has to provide protection for mucous membranes (eyes) as well. The most suitable devices are full masks and safety hoods. It is important to take devices, which cannot protect mucous membranes, into consideration. In case of industrial catastro- phe, we might suppose that poisonous effects cause injuries not only through the air but that they can be absorbed through the eyes' mucous membranes. Dermic pollution will not have a lethal result, since the population is decontaminated on the border of the contaminated area. 
I am going to list the advantages and disadvantages of gas masks (whole masks) in the following. From the list it can be clearly seen what theses protective devices are good for.

Advantages of gas masks:

- changeable insertion, variable protection ability;

- good fit, low suction factor;

- less vulnerable implementation;

- relatively comfortable;

- long-lasting protection (even up to 50 hours).

Disadvantages of gas masks:

- experience is needed;

- expensive;

- not universal in size.

From the facts above, it can be concluded that gas masks are less suitable as personal protective devices for the population. In fact, differences in size can be eliminated if the distribution is done according to names and families yet masks might not be stored and applied in the proper way. In my opinion, gas masks are much more useful for the workers in the contaminated area or people who participate in the work of decontamination than for the residents living in the area. As a consequence, civilians need a device, which is cheap, can be well-stored at their homes, universal and of course protects from dangers. Next, I am investigating the advantages and disadvantages of safety hoods.

Advantages of safety hoods:

- cheap;

- training is not needed, it can easily be applied;

- universal in size.

Disadvantages of safety hoods:

- unchangeable insertion;

- unsuitable for work;

- vulnerable;

- provides lower protection ability;

- limited protection.

In spite of the fact that safety hoods have a lower protection ability than gas masks, they are more easily applicable for the population. The most important aim after decontamination is to transport residents to the reception area as soon as possible. To my mind, the advantages of safety hoods make them suitable for the above mentioned aim because residents have to leave the contaminated area as quickly as possible.

\section{Plant workers, non-professional rescue workers}

In the event of a catastrophe plant workers are near the damaged zone. Plant workers and the leadership can give the most accurate information to people who take part in the rescue work. As chemical industries operate continuously, there are always workers on the site. In most cases they take the first steps and provide people with suitable protective equipment. Further- more, they accomplish general and professional exploration too. However, non-professional rescue organizations are not exposed to direct risks in all cases. In my opinion, their primary task is to create a stable background and support professional rescue organizations. 
Firm workers know the site well and they are extremely good at technology. Averting damage can be made more effective, harmful consequences and pollution can be reduced with the use of proper technology. If it is necessary plant workers have to show the emergen- cy routes, injured people, and damaged structures to professional rescue workers. In addition, they indicate damaged technological equipment. With the help of plant workers efficiency and safety of interferers can be boosted. Plant workers need to provide protection against sources of danger, hence they need to supply people with protective equipment. Personal pro- tective equipment should be supplied according to the safety documentation. It is necessary to examine what type of toxic substance may appear at the firm (materials before and after processing and other materials coming from operation as well) according to which personal protective equipment is needed. The following aspects should be taken into consideration when selecting adequate protective devices:

- jeopardizing effects (firm specific);

- protection ability (depends on jeopardizing effects);

- work comfort.

In case of industrial accidents, plant workers are the first to intervene so work comfort is really significant. In an exceptional case, till the arrival of the ambulance an hour may pass when the first independent intervention happens. So protection ability has to be selected in a way that in case of need it should be applicable for about 2 or 3 hours. Non-professional rescue organizations join damage prevention after professional rescue organizations have fulfilled their duties. After alarming non-professional rescue organizations, they can not im- mediately be deployed. To deploy them some time is needed, it can last from a few hours up to a day. Previously tasks by professional rescue organizations have already been introduced. In Hungary Hussar or "Huszár" - in Hungarian —, is an average category rescue organi- zation, consisting of volunteers. They have the right devices to accomplish their tasks and also members have the appropriate qualification to use these devices. Fulfilling tasks in the damaged zone and along the border of it needs adequate personal protection. Devices should be selected from the aspect of jeopardizing effects. These effects are unpredictable. There are several jeopardizing factors in a damaged zone. For non-professional rescue organizations it is recommended to use universal equipment with regard to protective ability - mainly respiratory devices - what is more, they have to be versatile. Non-professional rescue orga- nizations should examine what type of damaged zones they intend to act in effectively. If a rescue organization wants to efficiently intervene in more damaged zones, universal devices are not the most adequate. This study examines the significance of requirements in regard to personal protective devices in the area of industrial catastrophes. When non-professional rescue organizations supply residents with personal protective equipment, the following fea- tures should be taken into consideration:

- universal protection ability;

- necessary and sufficient protection (depending on the task);

- work comfort.

Non-professional rescue organizations select personal protective devices according to the types of catastrophes. In addition, they can be packed in unified kits. It is essential to create a proper economic and logistic background. The latter is also important because it can lead to serious problems if the rescue organization gets unified kits for forest fires or floods in case of an industrial catastrophe. 


\section{Professional rescue organizations}

From the professional rescue organizations point of view, during damage prevention they are the first interferers except for plant workers. Today, in Hungary the most suitable organiza- tion for immediate deployment is a professional fire brigade. After being alerted, the motion of the fire brigade starts within two minutes. In certain situations they can arrive within a few minutes. After contact and checking data, the fire brigade applies the systematized personal protective devices and starts intervening. If less or nothing is known accurately about the substance getting out during an industrial accident, the fire brigade uses a personal protective device of which the ability is on the highest level. In this case, it is type "A" gastight suit and pneumatic pressure respiratory device. Type "A" suits are always packed on the fireman's vehicles. Firemen have neither time nor opportunities to prognose the situation based on the information given during alerting. So they do not know what type of personal equipment is needed at the site. Since the fire brigade is one of the most special professional rescue organi- zation, they have to apply personal protective devices of which the ability is on the possible highest level. Other professional rescue organizations for whom alerting and quickness are not so strict, have the choice to select the necessary personal protective devices. I intend to examine the most complicated professional rescue organization, the official fire brigade. In general, accomplishing tasks wearing type an " $\mathrm{A}$ " gastight suit is a very hard task and fire- men exert themselves during work. It was essential to limit the requirements of comfort, they are inversely proportional to each other. The more comfortable a dress is, the less protective ability it has and the higher the protective ability is, the lower the level of work comfort is.

93M filter type clothing and Trellchem Super Gastight Suits are simple examples for the above mentioned facts.
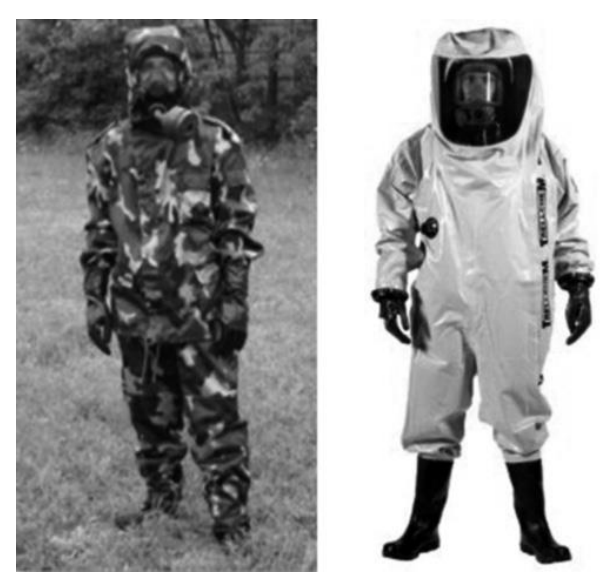

Picture 1.93 filter type clothing (side left)'; Trellchem Super Gastight Suit (side right $)^{3}$.

$293 \mathrm{M}$ filter type protective clothing http://www.respirator.hu/?module=products\&site=main\&group=sajat_katonairendeltetesu\&menupath=sajat_ katonairendeltetesu\&product=93Mvedoruha\&lang=hun (downloaded: 2311 2012)

3 Tellchem Super Gastight Suits

http://protective.ansell.com/en/Products/Trellchem/Gastight-Suits/Trellchem-Super/ (downloaded: 2311 2012) 
Apart from the fire brigade, other professional rescue organizations, such as the military, HUNOR etc, can come to the site as well. However, the latter ones might arrive in hours, they have the opportunity to decide what kind of personal protective devices to use in the damage zone. The most important and basic tasks are done by the ambulance brigade. For them, it is significant to use personal devices with the highest level of ability.

\section{Conclusion}

In this article I divided people in the damage zone into three big groups. With the help of the groups I defined types of tasks of damage prevention. On the basis of the task requirements personal protective equipment are defined. When damage occurs (plant workers) or after the occurrence of damage a professional rescue organization (currently it is the fire brigade in Hungary) has to supply the highest level of protection. As for the firm workers, it is a lot easier since the firm is able to prepare for the specific sources of danger, while the fire brigade

- taking quick reaction time into consideration - is on the maximum level with regard to personal protection. The intervening ability of other professional or non-professional rescue organizations depends on their personal protective equipment.

In an ideal case, unified kits can be made specifically for industrial catastrophes. (e.g. re- lease of combustible liquid, poisonous liquid, dusting of toxic, solid substance). In Hungary, rescue organizations do not have the available resources to systematize unified kits. Mainly, they apply universal personal protective equipment, of which the protection ability is high. However, effective work is harmfully influenced by the problems arising from work comfort. Apart from the economic aspect, efficient exploration and a logistics background is necessary to organize personal protective equipment supply for a catastrophe.

\section{References}

[1] 2011. évi CXXVIII. törvény a katasztrófavédelemröl és a hozzá kapcsolódó egyes törvények módositásáról. (Act 2011 CXXVIII. on disaster management and on the amendment of individual, related acts). http://net.jogtar.hu/jr/gen/hjegy_doc.cgi?docid=A1100128. TV\&celpara=\#xcelparam (downloaded: 1811 2012)

[2] CSEH G., DEÁK GY., KÁTAI-URBÁN L., KOZMA S., POPELYÁK P., SÁNDOR A., SZAKÁL B., VASS GY.: Ipari biztonsági kézikönyv. (Handbook on Industrial Safety). Budapest: KJK Kerszöv Jogi és Üzleti Kiadó Kft., 2003.

[3] SZAKÁL B., CIMER ZS., KÁTAI-URBÁN L., VASS GY.: Iparbiztonság II.: A veszélyes anyagokkal kapcsolatos súlyos balesetek következményei és kockázatai. (Industrial Safety II. Consequences and Risks of Major Accidents involving Dangerous Substances). Budapest: TERC Kereskedelmi és Szolgáltató Kft., 2013.

[4] BOGNÁR B., KÁTAI-URBÁN L., KOSSA Gy., KOZMA S., SZAKÁL B., VASS Gyy.: In. KÁTAI-URBÁN L. (Ed.), Iparbiztonságtan I.: Kézikönyv az iparbiztonsági üzemeltetői és hatósági feladatok ellátásához. (Industrial Safety I. Handbook on Implementation's Tasks of Operators and Authorities). Budapest: Nemzeti Közszolgálati és Tankönyvkiadó, 2013. ISBN 9786155344121 
LACZIK Balázs: Methods and principles of unified personal protective equipment...

[5] JÁVORKA G.: Polgári védelem. (Civil Protection). Baja: Eötvös József Főiskola, főiskolai jegyzet.

[6] 2/2002. (II. 7.) SzCsM rendelet az egyéni védőeszközök követelményeiröl és megfelelöségének tanúsitásáról. (Ministerial Order N. 2/2002. (II. 7.) Minister of social and family affairs on the requirements of the individual protective equipment). www.bimeo.hu/2_2002_SzCsM.htm (downloaded: 2311 2012)

[7] ALTUNYIN, T.: Katasztrófák elleni harc. (Protection against Disasters). Budapest: Zrínyi Katonai Kiadó, 1983.

[8] MIHNO, E. P.: Elemi csapások, természeti és ipari katasztrófák következményeinek felszámolása. (Mitigation of the consequences of the natural and industrial disasters). Budapest: Épitésügyi Tájékoztatási Központ, 1984. 